\title{
Income Disparity among Urban and Rural Community in Sri Lanka
}

\author{
R.R.H. Chandrasiri ${ }^{1}$ \& A.A. Shantha ${ }^{2}$ \\ ${ }^{1,2}$ Department of Economics and Statistics \\ Faculty of Social Sciences and Languages \\ Sabaragamuwa University of Sri Lanka \\ Belihuloya \\ SRI LANKA \\ $\underline{\text { rashmi.himasha321@gmail.com }}{ }^{1,} \underline{\text { arunaeconomics999@gmail.com² }}$
}

\begin{abstract}
Income disparity is considered as a global problem, with significant manifestations in the Sri Lankan context. This research investigates the income disparities between urban and rural populations in Sri Lanka. The objective is to investigate the degree of income inequality within and between sectors. The survey included 166 households. Since the study compared urban and rural communities, the same sample size was taken from both sectors. The study was carried out using multiple linear regression, with the Gini coefficient and Lorenz curve used to determine the degree of inequalities. According to the study's findings, the composite assessment of income disparities across sectors accounted for 0.25 Gini coefficient. According to the study, rural families' breadwinners should be financially supported. In order to reduce the degree of inequality, the government should take steps to improve rural infrastructure, schooling, and health care at a pace comparable to that of the urban sector.
\end{abstract}

Keywords:- Income disparity, urban, rural, Gini coefficient

\section{INTRODUCTION}

Economic inequality is considered multi-dimensional; income, consumption and wealth. The difference identified between different groups of people in different levels of income earned and overall standards of wellbeing refers to income disparity (Kyroglou, 2017). On the other hand income inequality is created because of rising inequality in wages and salaries, within high and low skilled workers, between developed and developing countries as well as between different groups of people (Piketty, 2014). These different groups may refer to whole countries, or local groups, national or regional groups or else individuals (Atkinson, 2015). Most of the time income disparity is used as a well-being indicator 
or an economic indicator within the countries (Kyroglou, 2017). There are many reasons for income disparity mentioned by some researchers. One of the reason is the earning gaps between high skilled and low skilled groups and among developed and developing countries (Piketty, 2014). The emerging of urbanization, globalization and higher automation of business activities in the present has created a gap between wages and salaries and excessive skills are required to earn high salary are some more reasons (Navarro, 2007). In rural areas less access to public goods, good education, infrastructure, high job opportunities and some other geographically related factors may generate lower returns and welfare to poor groups (De Silva, 2013).

Wilkinson and Pickett (2009) showed that there are some important consequences and social implications of income disparity. Recent data reveals that many additional societal issues, such as mental illness, violence, lack of trust, adolescent births, obesity, drug misuse, and low scholastic achievement of students, are more frequent in more unequal countries. According to certain academic literature income disparity affects growth negatively (Shantha \& Ali 2013b). Inequality limits investment possibilities, diminishes borrower incentives, slows growth by boosting fertility rates, and causes macroeconomic volatility (Atkinson \& Morelli, 2011). Consumers of middle and low class lapse behind in terms of confidence and status and consumers attempt to compensate for the damage by consuming beyond their abilities. Therefore, these two classes get into debt, and this may ultimately causes their purchasing ability to drop substantially further, and also affects the economy negatively (Atkinson \& Morelli, 2011). Researchers had found that income inequality include some consequences such as, higher rates of social problems, health problems, low level of social benefits, lower population happiness and satisfaction and even lower level of growth in the economy (Wilkinson \& Pickett, 2009; Yang, 1999; De Silva, 2013).

Reducing disparity is one of the most important step that countries can take to increase community well-being, distribute people's incomes fairly and increase the country's overall economic growth (Asad \& Ahmad, 2011). Therefore, eradicating inequality in Sri Lanka at microeconomic level would reduce excessive health spending and increase educational performance of the poor. At macroeconomic aspect reducing disparity would increase growth and build a stabilized economy (De Silva 2013). 
In Sri Lanka, there are three sectors in the country as, urban, rural and estate. For this study urban and rural sectors are considered. Some researchers define urban areas or urbanization as it is not just the change of land use, but also the changes in socio-economic aspects (eg ; income levels, educational standards, job opportunities and population) (Madsen, Kristensen , Fertner, Busck \& Jorgensen, 2010). According to the Household Income and Expenditure Survey report 2016 in Sri Lanka, urban areas are defined as areas which are governed by Municipal councils (MC) or urban councils (UC). Areas which are far away from urban influence can be categorized as traditional rural areas with low population density, low income level and a high degree of primary production (Madsen et al., 2010). According to Menike (2015) study shows that a wide unbalanced difference in advancement between the country's rural and urban sectors could be well identified. Therefore a reasonable disparity can be seen in between these two sectors.

This study mainly examine the degree of income disparity between urban and rural community in Sri Lanka following with some sub objectives; to identify the household income differences and to identify the factors that impact on income disparity. Though there are number of studies that have examined about income disparity around the world, but it is difficult to find empirical and theoretical research studies carried out for the Sri Lankan economy. Thus there exists a clear literature gap in Sri Lanka, therefore this study will be useful for further implications.

\subsection{Problem statement}

Most of the studies had limited their studies to analyze one dimension. But studying two or three dimensions broaden, deepen and expand the understanding and evaluation of disparity (Fisher, Johnson, Smeeding\& Thompson, 2017). Income disparity is generating consequences and social implications between different groups. The high inequality level within a country generally shows high levels of crimes and social insecurity, especially for lower income people. Compared to higher income people, lower income groups face high level of injustice (Wilkinson \& Pickett, 2009). Disparity in income can be identified between same group, different groups or countries in different periods of time (Lambert \& Aronson, 1993). Sapolsky (2005) mentioned that countries with high income inequality is associated with health care problems such as, only the high income groups can access to healthcare services and 
therefore, low income groups are facing more health problems. As already mentioned countries with high income disparities face important social problems, with unrest, social instability and crime at the frontline and all of those weaken the social instability or cohesion of a country (Wilkinson \& Pickett, 2009).

Disparity in income, in economic context undermines aggregate demand for goods and services. Therefore, it affects consumption negatively. Furthermore, the disparity in income is related with high level of unemployment causing more household debt (Quintana \& Royuela, 2012). However, globally disparity in income is a major issue which should be concerned more. Many countries failed to reduce income inequality within country and therefore this inequality benefit wealthy and hurts poor (Atkinson \& Morelli, 2011). In the world many developed as well as developing countries are experiencing increases in inequality within country since 1980s. The expanding of income disparity has gone hand in hand with the period of increasing countries exposure to globalization via cross border flows of goods, services, capital and labour.

In developed countries, earnings inequality, differences in educational level has created the disparity in income with increasing inequality. And in developing countries, according to the Kuznets identified that people shiftment to modern activities from traditional has been an important reason for inverted $U$ relationship within development and inequality. Therefore developing countries account for larger amount of disparity than developed countries (Arun \& Borooah, 2004; Katz \& Murphy, 1992). United States along with UK and rich OECD (Organization for Economic Co-operation and Development) countries features the highest level of disparity in income and faced to the highest growth in disparities (Neckerman \& Torche, 2007; Smeeding, 2005). Wodon and Yitzhaki (2002) stated higher level of disparity may lead to poverty within the country. The share of the benefits of the poor may reduce due to high inequality.

The concept of inequality has a direct and negative impact on social welfare. Considering Sri Lanka, government has provided access to basic social services and facilities to most of the sectors and regions. Despite that gains and benefits are largely limited to Colombo and closer by districts. The regions that are far away from Colombo, shows poor facilities, opportunities than areas closer to Colombo. Although, Sri Lanka has been recording 
moderate economic growth during a certain period still inequality exists in the country (Kumara, 2012). A significant gap can be seen between urban and rural community in many ways such as, communication barriers, quality of education, geographical aspects, opportunities and many more (De Silva, 2013; Menike, 2015; Kumara, 2012).

In Sri Lanka there are limited number of research that focus on either income or consumption inequality. Though there are number of studies that have examined about income disparity around the world, but it is difficult to find empirical studies carried out for the Sri Lankan economy. Thus there exists a clear literature gap in Sri Lanka regarding a comparison between these two sectors using income disparity. In Sri Lanka according to the latest Household Income and Expenditure survey data, the richest $20 \%$ of the country receives nearly $51 \%$ of the Sri Lanka total income and 5\% was distributed among the $20 \%$ of the poorest (HIES Report, 2016). Therefore this study examine the income gaps between urban and rural community and this study will be useful for further implications regarding this problem in the country.

Therefore this research study investigates the problems of whether "there is an income disparity among urban and rural community in Sri Lanka and what key determinants that affects income disparity?"

The main objective of the study is to explore the degree of income disparity within and between sectors. Specific objectives of the study are, to investigate the disparities in income levels between the urban and rural communities in Sri Lanka and identify the determinants of income disparity in rural and urban settings of Sri Lanka.

\subsection{Literature review and hypotheses}

Consequently, income inequality refers to the difference in income distribution (OECD, 2015). The study of income disparity has a rich history, going back to the classical school of economics and the studies of prominent classical economists including Adam Smith and David Ricardo. For Adam Smith a society of which the bulk of its members are disadvantaged cannot reach high growth rates (Atkinson, 1997). Income disparity can be observed as one of the dimensions of disparity (Wilkinson \& Piketty, 2009; Kawachi, Kennedy, Lochner \& Prothrow-Stith, 1997; Babones, 2008). Kyroglou (2017) mentioned income disparity may be observed between the same groups or nations in various 
historic periods, taking into account the variations in economic patterns that people have adopted overtime. Base on economic context, income disparity reduces aggregate demand for goods and services, adversely impacting consumption as well (Quintana \& Royuela, 2012). Numerous measures of inequality will not rely on absolute degree of well-being attained in the society. In other words, income disparity measures generally do not rely on the mean income estimated in a country. This is also common for two countries, one very wealthy and one very poor, to have the same degree of income disparity (Wodon \& Yizhaki, 2002).

Wodon and Yizhaki (2002) mentioned that individuals and household should not only evaluate their level of welfare in terms their actual levels of income and expenditure, they even distinguish themselves with each other. Therefore, every given amount income in a region high inequality has a clear negative impact on welfare. As well as inequality interacts with disparities in well-being between households (or individuals) and not with the degree of well-being attained by those households. Disparity and poverty are definitely among the key problems of developing world. Combat against inequality and power are main priorities of the developing world. The issues of global inequality are highly significant, but it is still a primary local concern. Because people are particularly bothered about disparity within their country. So policies are aimed at minimizing disparity around people inside national boundaries (Alvaredo \& Gasparini, 2013).

Rising inequality in wages and salaries, within high and low skilled workers, between developed and developing countries as well as between different groups of people creates disparity (Piketty, 2014). These different groups may be refer to whole countries, or local groups, national or regional groups or else individuals (Atkinson, 2015). Most of the time income disparity is used as a well-being indicator or an economic indicator within the countries (Kyroglou, 2017). Wilkinson and Pickett (2009) showed that there are some important consequences and social implications of income disparity. Researchers had found that income inequality include some consequences such as, higher rates of social problems, health problems, low level of social benefits, lower population happiness and satisfaction and even lower level of growth in the economy. The high inequality level within a country generally shows high levels of crimes and social insecurity, especially for lower income people. Compared to higher income people, lower income groups face high level of injustice. Countries with high 
income inequality is associated with health care problems such as, only the high income groups can access to healthcare services and therefore, low income groups are facing more health problems. As already mentioned countries with high income disparities face important social problems, with unrest, social instability and crime at the frontline and all of those weaken the social instability or cohesion of a country (Wilkinson \& Pickett, 2009).

Income disparity can be measured using household disposable income and it includes wages, salaries asset income and transfer income (Ravallion \& Chen, 2011). The sum of household earnings, transfer payments, pension benefits, capital income and income from financial assets and social security contributions are components of disposable income (Japelli \& Pistaferri, 2009). In this study the sum of wages and salaries and self-employment income is known as earnings of an individual. Labour income includes wages, salaries, bonuses, non-labour income and capital income consists of rent, dividends, interest, business profits, capital gains and other income from owning assets. But disposable income is known as income after taxes and government transfers. Wealth is considered as a stock. The wealth is identified as the sum of financial and non-financial assets and net financial liabilities. It refers to the overall capital owned at a given point in time.

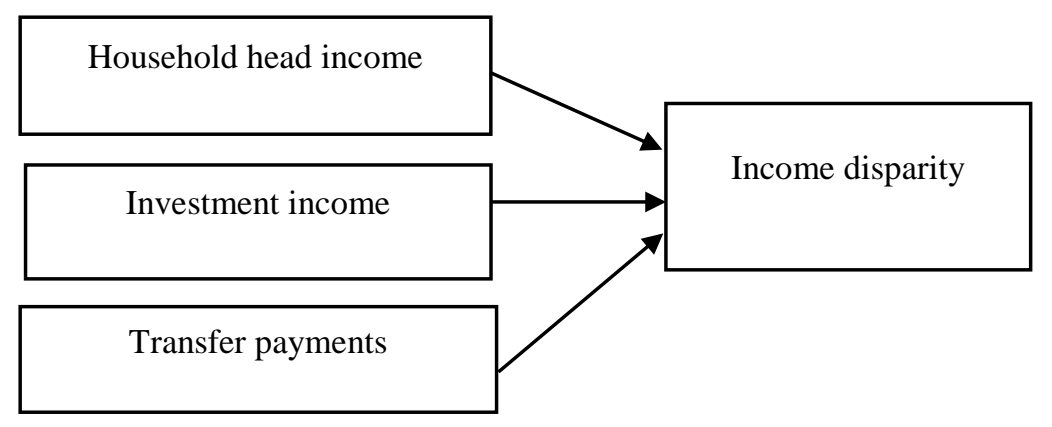

Figure 1: Conceptual framework

H1: There is a significant relationship between household income and employment earnings of household head.
In this study the sum of wages and salaries and self-employment income is known as earnings of an individual. Piketty and Saize 
(2014) stated that income is a flow variable. Household heads income consists of employment income (wages, salaries, allowances, bonuses,) seasonal agricultural income (paddy, onions etc.) other agricultural income (tea, rubber, coconut, egg and etc.) non-agricultural income (hotels, mining, transport) (Arun \& Borooah, 2004; Heathcote, Perri \& Violante, 2009).

H2: There is a significant relationship between household income and investment income.

Labour income includes wages, salaries, bonuses, non-labour income and capital income consists of rent, dividends, interest, business profits, capital gains and other income from owning assets. People holds various kind of assets which generates income out of them (Ravallion \& Chen, 2011; Japelli \& Pistaferri, 2009; Piketty \& Saize, 2014).

H3: There is a significant relationship between household income and transfer payments.

The sum of household earnings, transfer payments, capital income and income from financial assets and social security contributions are components of disposable income (Japelli \& Pistaferri, 2009). Transfer payments include, pension benefits, disability payments, government transfers etc. (Ravallion \& Chen, 2011; Piketty \& Saize, 2014; Menike, 2015); Arun \& Borooah, 2004).

\section{METHODS}

Table 1: Operationalization of variables

\begin{tabular}{|c|c|c|}
\hline Determinants/Indicators & Variables or Dimensions & Author \\
\hline Employment earnings & $\begin{array}{l}\text { Wages, salaries, seasonal } \\
\text { agricultural income } \\
\text { (paddy, onions etc.) other } \\
\text { agricultural income (tea, } \\
\text { rubber, coconut, egg, and } \\
\text { etc.) non-agricultural } \\
\text { income (hotels, mining, } \\
\text { transport) }\end{array}$ & $\begin{array}{lrr}\text { Ravallion } & \text { \& } & \text { Chen } \\
(2011) ; & \text { Japelli \& } \\
\text { Pistaferri } & \text { (2009); } \\
\text { Piketty \& } & \text { Saize } \\
(2014) ; & \text { Menike } \\
(2015) ; & \text { Arun \& } \\
\text { Borooah } & \text { (2004); } \\
\text { Heathcote et al., } \\
\text { (2009) }\end{array}$ \\
\hline Investment income & $\begin{array}{l}\text { Financial assets, Property } \\
\text { income, dividends }\end{array}$ & $\begin{array}{l}\text { Ravallion \& } \text { Chen } \\
\text { (2011); Japelli \& } \\
\text { Pistaferri (2009); }\end{array}$ \\
\hline
\end{tabular}




\begin{tabular}{|c|c|c|}
\hline & & $\begin{array}{lrr}\text { Piketty } & \& & \text { Saize } \\
(2014) ; & & \text { Menike } \\
(2015) ; & \text { Arun } \& \\
\text { Borooah } & & (2004) ; \\
\text { Heathcote } & \text { et al., } \\
(2009) & & \end{array}$ \\
\hline $\begin{array}{l}\text { Transfer payments/cash } \\
\text { receipts }\end{array}$ & $\begin{array}{l}\text { Government transfers, } \\
\text { pension payments, foreign } \\
\text { remittances }\end{array}$ & $\begin{array}{l}\text { Ravallion \& Chen } \\
(2011) ; \text { Piketty \& } \\
\text { Saize (2014); Menike } \\
(2015) ; \quad \text { Arun \& } \\
\text { Borooah (2004); } \\
\text { Heathcote et al., } \\
(2009)\end{array}$ \\
\hline
\end{tabular}

Source: Researchers' findings, 2020

\subsection{Research approach}

In here the study obtained crosssectional approach. This approach involves the collection of information about some aspect of the phenomena of the present situation. There are mainly another two ways of conducting a research; such as, qualitative approach and quantitative approach. For this study quantitative approach is used. To achieve the objectives of the study a questionnaire was used to obtain the needed data and views of the participants.

\subsection{Population}

Population refers to all the items or people in a group which the researcher expected to examine. As this study is mainly exploring the consumption and income disparity among urban and rural community, the household units will be considered as the population. For this study 36,092 households under Negombo Municipal Council and 16,880 households under Imbulpe Pradeshiya Sabha was decided. Therefore, altogether 52,972 household units in both areas was selected as the total population in this study.

\subsection{Sample}

The Multi-stage cluster sampling method was used to select participants for the study, the reason that it is a type of sampling which involves dividing the population into groups. Equally 3 GN divisions from each local authority was selected to the sample frame. Under Negombo Municipal Council, 3353 households were chosen from Bolawalana, Periyamulla and Angurukaramulla GN divisions. As well as under Imbulpe Pradeshiya Sabha, 899 
households were selected for the sample frame respectively from Muttettuwegama,

Karagasthalawa and Kinchigune GN divisions. The participants of the study was household heads who were above 20 years old. 166 households was taken as the sample, 83 from both areas.

Table 2: Sample selection

\begin{tabular}{|c|c|c|}
\hline GN division & Population & Sample \\
\hline \multicolumn{3}{|c|}{ Negombo Municipal Council } \\
\hline Bolawalana & 1435 & 36 \\
\hline Periyamulla & 911 & 24 \\
\hline Angurukaramulla & 1007 & 23 \\
\hline \multicolumn{3}{|c|}{ Imbulpe Pradeshiya Sabha } \\
\hline Muttettuwegama & 505 & 46 \\
\hline Karagasthalawa & 239 & 22 \\
\hline Kinchigune & 155 & 15 \\
\hline Total & $\overline{4252}$ & 166 \\
\hline
\end{tabular}

Source: Survey findings, 2020

\subsection{Data collection}

This research mainly depends on primary data that was collected by the researcher. For this study data was collected through a survey and a face to face interview. A Structured questionnaire was used for the process of data collection.

\subsection{Method of analysis}

Main objective of the study is to identify income disparity among urban and rural communities in
Sri Lanka. There are number of measures used to calculate inequality; Gini coefficient, Lorenz curve, Theil's index, Atkinson index, Relative mean deviation and Coefficient of variation etc. For this study Gini coefficient and Lorenz curve was used. Gini coefficient is the most widely used indicator of disparity due to its desirable properties that guide the policy analysis. As well as Gini coefficient is also a solely mathematical indicator of uncertainty and a standard measure of inequality. The 
graphical representation of Gini coefficient is the Lorenz curve. To explore the factors affecting income disparity multiple linear regression model was utilized. Multiple regression analysis is used when there is more than 2 independent variables. The significance level of the $\beta$ coefficients are checked using the $P$ values and the $R$ square value was used to express the goodness of fit of the model. ANOVA table was used to test the overall significance level of the model. The Pearson correlation analysis and ANOVA table was used to explain the relationship between continuous and continuous variables and categorical variables with continuous variable. Only the independent variables which have a significant relationship was taken to the analysis. The normality distribution of the dependent variable were analyzed using Kolmogorov-Smirnov test.

\section{RESULTS}

\subsection{Inequality analysis}

According to this analysis regarding the rural sector the income inequality Gini coefficient is 0.20 . Therefore, there is a disparity between rural household incomes. But the value is close to zero because the income variation among households were not so large. According to the field data obtained most of them were engaged in normal jobs such as, three-weel drivers, security officers and laborers'. So the individual level of income does not express a huge variation.

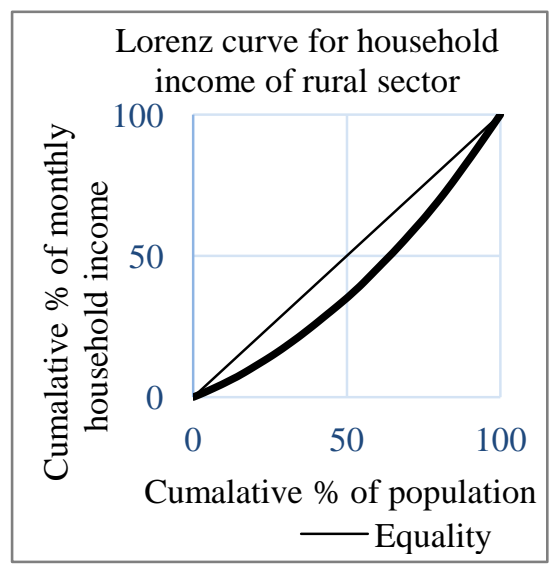

Figure 2: Lorenz curve

Source: Survey findings, 2020

Lorenz curve is away from the $45^{\circ}$ line of equality. Therefore, income disparity can be seen among the group. According to the graph poorest $20 \%$ of the population receives $11 \%$ of the total income, the richest $20 \%$ of the population receives almost $30 \%$ of the total income and the middle $60 \%$ of the population receives $59 \%$ of the total income.

According to the analysis of the urban sector the income inequality Gini coefficient is 0.17 . Therefore, there is a disparity between household income levels in urban sector. But the value is close to zero because the income variation among households were not so 
large. According to the field data obtained most of them were engaged in professional jobs such as, managers, engineers etc. and most of them were businessmen. So the income levels does not express a huge variation.

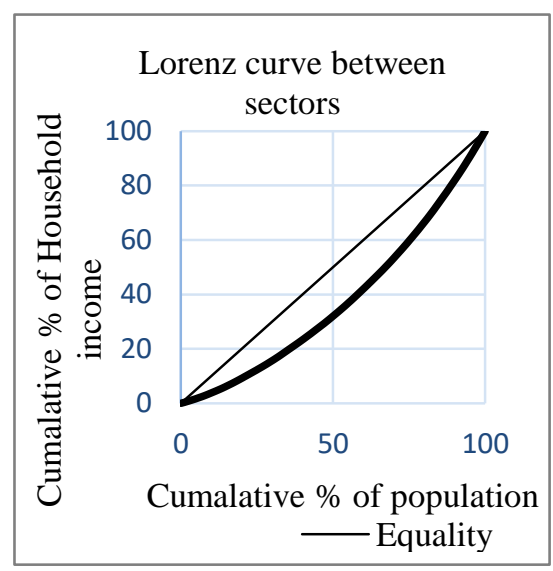

Figure 3: Lorenz curve

Source: Survey findings, 2020

According to the graph $20 \%$ of the population received $12 \%$ of the total income, the richest $20 \%$ of the population receives almost $27 \%$ of the total income and the middle $60 \%$ of the population receives $61 \%$ of the total income.

According to this analysis the income inequality Gini coefficient is 0.25 . Therefore, there is a disparity between urban and rural community. The disparity level is higher than the disparity levels when the two groups are separately analyzed. The reasons for that can be, high income variation between groups and various jobs (More professionals in urban sector).

The graph explains that poorest $20 \%$ of the population receives $9 \%$ of the total income, the richest $20 \%$ of the population receives almost $34 \%$ of the total income and the middle $60 \%$ of the population receives $57 \%$ of the total income.

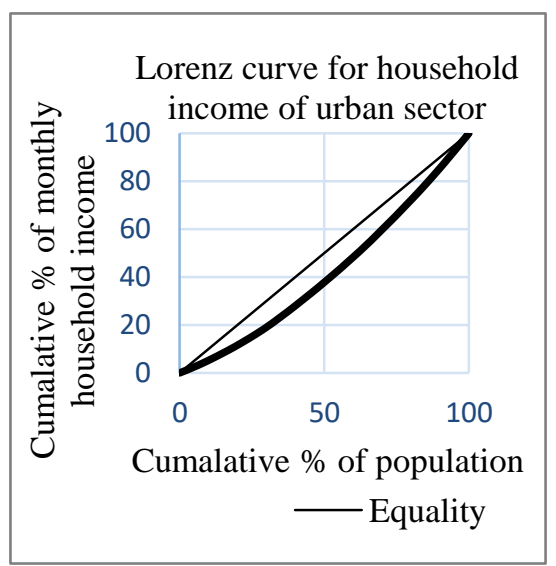

Figure 4: Lorenz curve

Source: Survey findings, 2020

Table 3: Income shared among groups

\begin{tabular}{|l|c|c|c|}
\hline \multirow{2}{*}{ Group } & \multicolumn{3}{|c|}{$\%$ of Income share } \\
\cline { 2 - 4 } & $\begin{array}{c}\text { Poore } \\
\text { st } \\
20 \%\end{array}$ & $\begin{array}{c}\text { Middl } \\
\text { e } 60 \%\end{array}$ & $\begin{array}{c}\text { Riches } \\
\text { t 20\% }\end{array}$ \\
\hline Rural & 11 & 59 & 30 \\
\hline Urban & 12 & 61 & 27 \\
\hline Pooled & 9 & 57 & 34 \\
\hline
\end{tabular}

Source: Survey Findings, 2020 


\subsection{Regression analysis}

The Model A will be rural consumption disparity and Model $\mathrm{B}$ will be urban consumption disparity. But before conducting the regression analysis the OLS assumptions must be fulfilled. Therefore, the researcher first tested the normality of the dependent variable based on the Kolmogorov-Smirnov test. The $\mathrm{P}$ values are greater than 0.05 significance level $(0.182>0.05$, $0.077>0.05$ ) respectively in both models, that means the dependent variable is normally distributed in both the models.

If variance inflation factor (VIF) value is greater than 10 and if the Tolerance value is less than 1 , it indicates that there is a multicollinearity situation. In here all the values does not exceed VIF value 10 and the
Tolerance value is more than 1 . It indicates that there is no multicollinearity problem in both models.

Finally, the researcher should select the appropriate independent variables to the regression model.

For the both models there were continuous as well as categorical independent variables. Therefore, to check the relationship between continuous dependent variable and categorical independent variables used ANOVA test. On the other hand, to check the association between continuous dependent variable and continuous independent variables used Pearson correlation technique. The multiple linear regression model was conducted using the appropriate variables as below.

Table 4: Multiple linear regression model

\begin{tabular}{|l|c|c|c|c|}
\hline & $\boldsymbol{\beta}$ & Std.error & $\mathbf{t}$ & Sig \\
\hline Constant & 17943.99 & 3055.61 & 5.872 & 0.000 \\
\hline $\begin{array}{l}\text { Household Head } \\
\text { income }\end{array}$ & 0.637 & 0.070 & 8.996 & 0.000 \\
\hline Transfer payment & 0.232 & 0.144 & 1.610 & 0.111 \\
\hline $\begin{array}{l}\text { Investment } \\
\text { income }\end{array}$ & 0.461 & 0.300 & 1.537 & 0.128 \\
\hline
\end{tabular}

Source: Survey Findings, 2020 


\section{Chandrasiri R.R.H., \& Shantha A.A., Wayamba Journal of Management 12 (1)}

In the rural model all the independent variables have a positive relationship to the dependent variable. But only household head income variable was significant. The investment income and the transfer payment variables were not significant. There were only 10 households who has an income from investments such as, boarding fees and rent from some properties. When all the independent variables remaining constant, the household income is 17943.998 rupees. When all the other variables held constant, a rupee change in household head income, increase the household income by 0.637 rupees. When all the other variables held constant, if transfer payment income is increased by one rupee, the household income increased by 0.232 rupees. When other variables held constant, if the investment income increased by one rupee, the household income increased by 0.461 rupees.

$\mathrm{R}$ square indicates that the proportion of variance in the dependent variable that can be explained by the independent variables. According to the results of the model summary, the adjusted $\mathrm{R}$ square of the study is $55.2 \%$ and it reveals that $55.2 \%$ of the data fit the regression model. Therefore, the researcher identified that the fitted model is good one.

Table 5: Multiple linear regression model

\begin{tabular}{|l|c|c|c|c|}
\hline & $\boldsymbol{\beta}$ & Std.error & $\mathbf{t}$ & Sig \\
\hline Constant & 57259.180 & 5594.824 & 10.234 & 0.000 \\
\hline Household Head income & 0.366 & 0.066 & 5.576 & 0.000 \\
\hline Transfer payment & -0.463 & 0.173 & -2.672 & 0.009 \\
\hline Investment income & 0.343 & 0.210 & 1.631 & 0.107 \\
\hline
\end{tabular}

Source: Survey findings, 2020

In the urban model all the independent variables have a positive relationship to the dependent variable except the transfer payment variable. The household head income as well as transfer payment variables have a significant relationship with the dependent variable. The investment income variables was not significant.

When all the independent variables remained constant, the household income is $57,259.180$ rupees. When all the other variables held constant, a rupee 
change in household head income, increase the household income by 0.366 rupees. When all the other variables held constant, if transfer payment income is increased by one rupee, the household income decreased by 0.463 rupees. When all the other variables held constant, if the investment income increased by one rupee, the household income increased by 0.343 rupees.

$\mathrm{R}$ square indicates that the proportion of variance in the dependent variable that can be explained by the independent variables. According to the results of the model summary, the adjusted $\mathrm{R}$ square of the study is $40.9 \%$ and it reveals that $40.9 \%$ of the data fit the regression model. Therefore, the researcher identified that the fitted model is good one.

\section{DISCUSSION}

Income disparity has been a world-wide problem. According to empirical results of Asad and Ahmad (2011) found that rural inequality was increasing and urban inequality was decreasing over the period. In this study also revealed that the income disparity level individually of the rural and urban sector was 0.20 and 0.17 respectively. Therefore, the within group inequality was lower than between group inequality. According to the analysis in the both the sectors income variation within their own sector was very low. Regarding the field data obtained from rural sector, most of them were laborers, three-wheel drivers or security officers. So, the income level between them does not express a huge variation. Out of the 83 households in the sample, most of them belongs to the group of non-agricultural activity earnings. Households in the urban sector were engaged in professional jobs and business activities. The Gini coefficient value for between group income disparities was 0.25. The disparity level is higher than the disparity levels when the two groups are observed individually. The reasons for a high Gini coefficient might be high variation of the income between groups, various job opportunities for the urban sector than the rural, technology, urbanization level and the education level of the urban people. The research findings released in 2011 by Pavcnik under the topic globalization and within-country income inequality realize that literature on globalization and disparity focuses on indices of discrimination that reflect income inequality between people across education, business and their job categories

Current regression on the income disparity models shows that not the same variables are significant in both models: Regarding the rural sector transfer payments and investment income variables 
were not significant and in the urban sector the investment income variable was not significant. This might be because of the collected data might be not enough or sometimes accurate data was not given by the households. In the rural sector there were only 10 people out of 83 has investment income. Sometimes the collected data might not be enough to obtain a more precise answer. In line with literature, Arun and Borooah (2004) examined the wage in equality in Sri Lanka. According to the reporting's of their analysis disparity in the distribution of investment income records 0.579 Gini coefficient which was greater than the inequality of distribution of employment earnings Gini coefficient 0.437 .

In addition to this regarding the rural sector most of them mentioned, that during the COVID- 19 situation they had a very hard life. Some people have lost the main income earning source such as small found cabins retail shops because they could not pay the rent on it. This data was collected for the month of August, and they were still rebuilding their ways of income. The impact covid-19 was a huge burden on their lives compared to urban households because most of the urban people has a permanent job for their own.

\section{CONCLUSION}

The breadwinners of the rural households need a permanent employment. Therefore, the researcher recommend that the government can take steps to develop small businesses in the area such as, new handy craft, clay products and bathik products. It will be an opportunity to them to increase their income levels. Proper training and financial assessments must be given by the government. This will be an opportunity for the households to be a part of national production. As a country we can increase our export capacity and this will be a way to attract more tourists to Sri Lanka. The infrastructure level of the area must be more developed. Government should take necessary steps to improve the infrastructure level in the area. A safe drinking water facility should be provided and a wellorganized health services and clinical care must be provided. The lack of proper hospital facility is a major problem to them.

In order to reduce the disparity following policy implications are proposed by the researcher. Rural development bank can provide more financial assistance to the small scale business people to strengthen their businesses. In addition to that all other financial authorities can introduce more opportunities to people to start new businesses and give hand to 
their new innovations. The Ministry of Industries, and take steps to generate new business opportunities for the rural community. In addition to that, proper training and awareness should be given to those people. The rural area which was selected to the survey is highly attracted area by local and foreign tourists. Therefore, to strengthen the low income families the relevant authorities can take steps. Specially, by implementing new business opportunities related to handy crafts, bathik and local food stalls. In many occasions the rural community have to face many difficulties regarding basic facilities. The relevant authorities must take steps to provide the basic needed facilities and maintain the ones that are already been disrupted.

\section{REFERENCES}

Alvaredo, F., \& Gasparini, L. (2013). Recent trends in inequality and poverty in developing countries. Handbook of Income Distribution, 2, 3-101.

Arun, T., \& Borooah, V. (2004). Earings inequality in Sri Lanka. Development Economy and Public Policy, 1-9.

Asad, M. A., \& Ahmad, M. (2011). Growth and Consumption Inequality in Pakistan. Pakistan
Economic and Social Review, 49(1), 69-89.

Atkinson, A. B. (1997). Bringing income distribution in from the cold. The Economic Journal, 107 (March), 297-321.

Atkinson, A. B. (2015). Inequality: what can be done. The London School of Economics and Political Science, 2-17.

Atkinson, A. B., \& Morelli, S. (2011). Economic crises and Inequality. United Nations Development Programme, 1-70.

Babones, S. J. (2008). Income inequality and population health. Social Science and Medicine, 66, 16141626.

De Silva, I. (2013). Endowments versus returns:

Counterfactual quantile decomposition of urbanrural inequality in Sri Lanka. Asian Development Bank. Colombo.Sri Lanka, 25(1), 48-60.

De Silva, I. (2013). Inequality decomposition by population subgroups and income sources in Sri Lanka. Journal of Economic Studies, 4-21.

Department of Census and Statistics. (2016). HIES Report. Sri Lanka. 
Fisher, J., Johnson, D., Smeeding, T., \& Thompson, J. (2017). Inequality in 3D:Income, consumption and wealth. Finance and Economics Discussion Series 2018-001, 2-24.

Heathcote, J., Perri, F., \& Violante, G. L. (2009). Unequal we stand: An empirical analysis of Economic inequality in the United States, 19672006. National Bureau of Economic Research, Working paper No:15483.

Jappelli, T., \& Pistaferri, L. (2009). Does consumption inequality track income inequality in Italy? Review of Economic Dynamics, 121.

Katz, L. F., \& Murphy, K. M. (1992). Changes in relative wages, 19631987. NBER Working Papers Series No:3927, 2-36.

Kawachi, I., Kennedy, B. P., Lochner, K., \& Prothrow-Stith, D. (1997). Social capital, income inequality and mortality. American Journal of Public Health, 87, No.09, 1491-1498.

Kumara, T. (2012). Decomposing spatial inequality in Sri Lanka: A quantile regression approach.

"Inequalities and

Development: new

challenges new

measurements? " (pp. 1-

26). Bordeaux, France:

University of Bordeaux.

Kyroglou, G. (2017). The importance of income inequality at the top end of the distribution as opposed to the bottom end as determinant of growth. 1-35.

Lambert, P. J., \& Aronson, J. R. (1993). Inequality decomposition analysis and the Gini coefficient revisited. The Economic Journal, 103(420), 12211227.

Madsen, M. F., Kristensen, S. P., Fertner, C., Busck, A. G., \& Jørgensen, G. (2010). Urbanisation of rural areas: A case study from Denmark. Geografisk Tidsskrift-Danish

Journal of Geography 110(1), 48-51.

Menike, H. A. (2015). Ruralurban disparity in Sri Lanka. IPASJ International Journal of Management, 1-12.

Narayan , A., \& Yoshida, N. (2005). Poverty in Sri Lanka: The impact of growth with rising inequality. World Bank Working Paper, 1-26. 
Navarro, V. (2007). Neoliberalism as a class ideology; or, the political causes of the growth of inequalities.

International Journal of Health Services, 31(1), 47-62.

Neckerman, K. M., \& Torche, F. (2007). Inequality: Causes and consequences. Annual Review of Sociology, Vol.33: 335-357.

OECD. (2015). Jobs, wages and inequality (forthcoming).

Pavcnik, N. (2011). Globalization and within-country income inequality. 233252.

Piketty, T. (2014). Capital in the Twenty-first century: A multidimensional approach to the history of capital and social classes. The British Journal of Sociology, 65(4), 737747.

Piketty, T., \& Saez, E. (2014). Inequality in the long run. Sciencemag, 344(6186), 838-843.

Quintana, D. C., \& Royuela, V. (2012). Unemployment and long-run economic growth:The role of income inequality and urbanisation.

Investigaciones

Regionales, 24, 153-173.
Ravallion, M., \& Chen, S. (2011). More relativelypoor people in a less absolutely-poor world. Policy Research Working Paper 6114, 2-40.

Sapolsky, R. (2005). Sick of poverty. Scientific American, 293(6), 92-99.

Shantha, A. A. (2017). The impact of uneven access to water on divergency of income among paddy farmers in the dry-zone of Sri Lanka. Australian Academy of Business and Economic Review, 03(2), 99-112.

Shantha, A. A., \& Ali Asan, B. (2013). Income inequality among major irrigation scheme in Sri Lanka: Gini decomposition approach. International Journal of Business Economic and Law, 02(2), 118-127.

Shantha, A. A., \& Ali Asan, B. (2013). The impact of uneven allocation of irrigation water on dynamics of agribusiness and income inequality: The case of Mahaweli development Project in Sri Lanka. 8th International Conference on Business Management, University Utara, Malaysia, 128135. 
Chandrasiri R.R.H., \& Shantha A.A., Wayamba Journal of Management 12 (1)

Smeeding, T. M. (2005). Public policy, Economic inequality, and poverty: The United States in comparative perspective. Social Science Quarterly, 86, 956-983.

Wilkinson, R. G., \& Pickett, K. E. (2009). Income inequality and social dysfunction. The Annual Review of Sociology, 35, 493-511.

Wodon, Q., \& Yitzhaki, S. (2002). Inequality and social welfare. MPRA Paper No. 12298, 1, 77100.

Yang, D. T. (1999). UrbanBiased policies and rising income inequality in China. 89(2), 306-309. 